\title{
PERAN FEAR OF MISSING OUT (FOMO) SEBAGAI MEDIATOR ANTARA KEPRIBADIAN DAN PENGGUNAAN INTERNET BERMASALAH
}

\author{
RistiaAngesti ${ }^{1}$ dan Imelda Dian Ika Oriza ${ }^{2}$ \\ ${ }^{1}$ Jurusan Psikologi , Universitas Indonesia \\ Email: ristia.angesti@ui.ac.id \\ ${ }^{2}$ Program Studi Psikologi, Universitas Indonesia \\ Email: imelda.ika@ui.ac.id
}

\begin{abstract}
Increasing internet users trigger problems in internet usage. In recent years, the phenomenon of the fear of missing out (FOMO) that has only emerged in recent years is thought to be a mediator between personality and problematic internet use. The purpose of this study is to see the influence of FOMO which acts as a mediator between personality and problematic internet use. The participants of this study are male $(N=39)$ and female $(N=143)$ participants with age range of $18-29$ years $(M=23.05, S D=2.7)$, namely in emerging adulthood with a total number of 182 participants. There are three measuring instruments used in this study, namely the scale of problematic internet use, personality scale, and the scale of fear of missing out. The data analysis used in this study is mediation analysis. The results obtained in this study is that neuroticism trait significantly affects FOMO, a = 0.268, $p<0.001$. Then, FOMO affects problematic internet usage significantly, $b=0.941, p<0.001$. Furthermore, neuroticism trait significantly affects problematic internet use through mediators, namely FOMO $c^{\prime}=0.615, p$ $<0.001$. The indirect effect obtained is 0.247 , the direct effect is 0.615 , and the total effect is 0.863 . The indirect effect of 0.247 on 10,000 sample bootstraps obtained true indirect effects ranging from 0.102 to 0.415 at $95 \%$ Confidence Interval (CI). Partial mediation between neuroticism trait and problematic internet use mediated by FOMO can be found. Then, there is perfect mediation between conscientiousness trait and problematic internet use mediated by FOMO. Through this research, it is proven that FOMO plays an important role as a mediator between personality and problematic internet use.
\end{abstract}

Keywords: neuroticism, conscientiousness, fear of missing out, problematic internet use.

\begin{abstract}
ABSTRAK
Pengguna internet yang semakin meningkat memicu permasalahan dalam penggunaan internet. Beberapa tahun terakhir, fenomena fear of missing out (FOMO) yang baru muncul beberapa tahun terakhir diduga dapat menjadi mediator antara kepribadian dan penggunaan internet bermasalah. Tujuan penelitian ini untuk melihat pengaruh FOMO yang berperan sebagai mediator antara kepribadian dan penggunaan internet bermasalah. Partisipan penelitian adalah partisipan berjenis kelamin laki- laki $(N=39)$ dan perempuan $(N=143)$ dengan rentang usia 18 29 tahun $(M=23.05, S D=2.7)$ yaitu pada emerging adulthood dengan jumlah total partisipan 182 orang. Terdapat tiga alat ukur yang digunakan dalam penelitian ini yaitu skala penggunaan internet bermasalah, skala kepribadian, dan skala fear of missing out. Analisis data yang digunakan dalam penelitian ini yaitu analisis mediasi. Hasil yang didapatkan dalam penelitian ini adalah trait neuroticism mempengaruhi FOMO secara signifikan, $a=0,268$, $p$ $<0,001$. Kemudian, FOMO mempengaruhi penggunaan internet bermasalah secara signifikan, $b=0,941, p<0,001$. Selanjutnya, trait neuroticism mempengaruhi penggunaan internet bermasalah melalui mediator yaitu FOMO secara signifikan, $c^{\prime}=0,615, p<0,001$. Maka diperoleh indirect effect sebesar 0,247, direct effect sebesar 0,615, dan total effect sebesar 0,863. Indirect effect sebesar 0,247 pada 10.000 bootstrap sampel dan diperoleh true indirect effect yang berkisar antara 0,102 hingga 0,415 pada 95\% Confidence Interval (CI). Dapat dilihat bahwa terdapat mediasi parsial antara trait neuroticism dengan penggunaan internet bermasalah yang dimediasi oleh FOMO. Kemudian, terdapat mediasi yang sempurna antara trait conscientiousness dengan penggunaan internet bermasalah yang dimediasi oleh FOMO. Melalui penelitian ini, membuktikan bahwa FOMO memiliki peran yang penting sebagai mediator antara kepribadian dan penggunaan internet bermasalah.
\end{abstract}

Kata kunci: neuroticism, conscientiousness, fear of missing out, penggunaan internet bermasalah. 


\section{PENDAHULUAN}

\section{Latar Belakang}

Pengguna internet di Indonesia terus mengalami peningkatan. Menurut APJII (Asosiasi Pengguna Jaringan Internet Indonesia) pengguna internet meningkat setiap tahun. APJII melaporkan bahwa dari 256,2 juta penduduk di Indonesia, yang menggunakan internet sebanyak 132,7 juta jiwa. Hal ini menunjukkan setengah dari penduduk Indonesia sudah menggunakan internet. APJII melakukan survei yang dibantu oleh Lembaga Polling Indonesia (LPI) menemukan bahwa pengguna internet terbanyak adalah pada rentang usia 20-39 tahun dengan total pengguna 93,6 juta dari 132,7 juta pengguna internet (APJII, 2016). Peningkatan pengguna internet terjadi karena internet telah menjadi sarana untuk melakukan segala hal dengan mudah dan cepat. Internet banyak memberikan hal positif dari beberapa aspek kehidupan masyarakat dengan kemudahan yang diberikan. Salah satunya, internet memberikan platform untuk berkomunikasi dengan menguatkan hubungan kekerabatan dan memberikan informasi real-time (Lenhart, 2015). Selain sisi positif yang didapatkan, internet juga memiliki dampak negatif terhadap beberapa pengguna internet. Internet juga dapat menimbulkan beberapa masalah jika tidak digunakan dengan tepat.

Istilah penggunaan internet bermasalah sebelumnya lebih dikenal dengan internet adiksi. Pada konteks permasalahan pada penggunaan internet, kata 'bermasalah' lebih digunakan secara global pada individu yang bermasalah dalam penggunaan internet dibandingkan dengan kata 'adiksi'. Kata 'adiksi' dianggap kurang tepat dalam menggambarkan perilaku individu yang bermasalah secara umum dalam penggunaan internet (Davis, 2001). Davis (2001) memberikan karakteristik pada penggunaan internet bermasalah lebih dari sekedar perilaku adiksi. Namun, ia membedakan pola pada penggunaan internet bermasalah menjadi kognisi yang berhubungan dengan internet dan perilaku negatif yang dihasilkan. Terdapat dua bentuk penggunaan internet bermasalah yaitu problematika secara spesifik dan umum. Penggunaan internet bermasalah yang spesifik yaitu termasuk pada penggunaan berlebihan pada konten internet (contoh: judi, stock trading, konten seksual). Pada penggunaan internet bermasalah secara umum, Davis memberikan konsep multidimensi penggunaan yang berlebihan pada internet itu sendiri yang menghasilkan peribadi yang negatif dan konsekuensinya. Individu tersebut menjadikan dirinya aktif untuk dalam jaringan (daring- online) internet sehingga ia lebih memilih untuk masuk dalam dunia virtual daripada berinteraksi tatap muka secara langsung.

Beberapa tahun terakhir, penelitian mengenai permasalahan dalam penggunaan internet mulai merebak. Pengunaan internet yang bermasalah dapat menimbulkan pengaruh negatif bagi penggunanya (Ceyhan, 2007). Terdapat hubungan antara mood dan kecemasan dengan pengunaan internet bermasalah yang mana individu cenderung mencari hubungan melalui daring (Gamez-Guadix, 2014). Penggunaan internet bermasalah juga dapat menurunkan kepuasan hidup, kecenderungan memiliki harga diri yang rendah, mudah depresi dan cenderung fear of missing out (FOMO) (Stead \& Bibby, 2017; Laconi, dkk, 2017; Kopunicova \& Baumgartner, 2016, \& Przybylski, dkk, 2013). Karakteristik kepribadian juga dapat mempengaruhi penggunaan internet bermasalah (Stead \& Bibby, 2017).

Kepribadian menjadi salah satu prediktor penggunaan internet bermasalah. Penelitian pada ranah kepribadian sudah cukup banyak dikaitakan dengan pengunaan internet bermasalah. Trait kepribadian (McCrae \& Costa, 2003) didefinisikan sebagai dimensi-dimensi perbedaan individu dengan kecenderungan untuk membentuk pola yang menetap pada pemikiran, perasaan, dan tindakan. Pada setiap individu memiliki beberapa trait yang dominan. Beberapa trait tertentu berkorelasi dan mempengaruhi penggunaan internet bermasalah (Stead \& Bibby, 2017; Laconi, 
dkk, 2017; Kopunicova \& Baumgartner, 2016; \& Floros \& Siomos, 2014). Trait extraversion dan conscientiousness berkorelasi negatif dengan penggunaan internet bermasalah (Stead \& Bibby, 2017; Kopunicova \& Baumgartner, 2016; \& Floros \& Siomos, 2014). Sebaliknya pada beberapa penelitian menemukan jika extraversion berkorelasi positif dengan penggunaan internet bermasalah (Jackson, dkk, 2003; \& Thorsteinsson \& Davey, 2014). Pada agreeableness berkorelasi negatif dengan penggunaan internet bermasalah (Stead \& Bibby, 2017; \& Floros \& Siomos, 2014) namun masih kurang kuat korelasi antara keduanya karena masih sedikit penelitian yang menemukan bahwa keduanya berkorelasi. Sedangkan, pada neuroticism berkorelasi positif dengan penggunaan internet bermasalah (Stead \& Bibby, 2017; Kopunicova \& Baumgartner, 2016; Jackson, dkk, 2003; Thorsteinsson \& Davey, 2014; \& Floros \& Siomos, 2014). Adanya perbedaan hasil tersebut memungkinan adanya variabel lain yang dapat menjadi mediator antara kepribadian dan internet bermasalah.

Penggunaan internet bermasalah juga dipengaruhi oleh fear of missing out (FOMO) (Stead \& Bibby, 2017). FOMO (Przybylski, dkk, 2013) dijelaskan sebagai ketakutan dan kecemasan yang dirasakan individu karena tidak terlibat dalam pengalaman menyenangkan bersama orang dekat disekitarnya sehingga membuat individu takut dan cemas akan diabaikan oleh mereka karena ia tidak terlibat dalam pengalaman tersebut. Pada penelitian ini, FOMO terkaitnya dengan daring internet. Karakteristik pada FOMO daring internet yaitu individu selalu memiliki keinginan untuk terus menerus mengetahui apa yang sedang orang disekitarnya lakukan dengan mengakses internet seperti memantau melalui sosial media atau media online lainnya. Mereka berusaha untuk selalu dapat terhubung sehingga ia sejalan dengan keadaan disekitarnya. Individu memiliki ketakutan dikeluarkan oleh kelompok pertemanan jika tidak mengetahui kabar terbaru pada hal-hal yang sedang terjadi. Karakteristik lainnya individu yang FOMO adalah memiliki regulasi diri yang rendah (Przybylski, dkk, 2013). Pembentukan konstruk FOMO berawal dari Self Determination Theory (SDT) yang memberikan perspektif untuk pemahaman yang lebih mendalam mengenai FOMO. Berdasarkan SDT (Przybylski, dkk, 2013), self-regulation yang efektif dan kesehatan secara psikologis dapat dilihat dari kepuasan pada tiga kebutuhan dasar psikologis pada individu yaitu: kompetensi, otonomi, dan keterhubungan. Dari kacamata teori ini, fenomena Fomo dapat dipahami sebagai buruknya self-regulation dan rendahnya kepuasan pada kebutuhan psikologis.

Penelitian pada mengenai FOMO dan penggunaan internet bermasalah sebagian besar masih berupa penelitian korelasi. Masih belum diketahui bagaimana peran FOMO dalam penggunaan internet bermasalah. Oberst, dkk (2016) menguatkan bahwa FOMO berperan sebagai mediasi antara gejala psikopatologikal depresi dan kecemasan dengan konsekuensi negatif penggunaan gawai. Hasil yang didapatkan bahwa FOMO memediasi secara total karena pengaruh langsung tidak terjadi antara gejala psikopatologikal kecemasan dengan konsekuensi negatif penggunaan gawai. Hal ini mengartikan bahwa FOMO memediasi antar kedua variabel tersebut. Penelitian lain oleh Przybylski, dkk (2013), juga menjadikan FOMO sebagai mediator antara mood dan social media engangement. Hasil yang didapatkan pun sesuai dengan prediksi bahwa FOMO dapat memediasi hubungan antara mood dan social media engangement. Pada penelitian Blackwell, dkk (2017) beberapa prediktor seperti kelekatan, neuroticism, dan usia dilihat pengaruhnya terhadap adiksi media sosial dengan analisis regresi hirarkikal dan didapatkan hasil bahwa semua prediktor tersebut mempengaruhi adiksi media sosial. Selanjutnya, ketika prediktor fear of missing out (FOMO) dimasukkan dalam tahap keempat regresi hirarkikal, variabel lainnya menjadi tidak signifikan. Hal ini membuktikan jika FOMO dapat menjadi mediator antara kelekatan, neuroticism, dan usia terhadap adiksi media sosial. Individu yang cenderung rendah conscientiousness dan tinggi pada neuroticism akan lebih mudah FOMO dan menggunakan internet secara bermasalah (Stead \& Bibby, 2017). Maka peneliti memberikan 
asumsi jika variabel Fear of missing out (FOMO) menjadi mediator antara trait conscientiousness dan neuroticism dan penggunaan internet bermasalah. FOMO memiliki peran yang cukup kuat sebagai perantara antara beberapa variabel dengan penggunaan internet bermasalah.

Neuroticism ditandai dengan kecenderungan untuk mudah cemas dan moody. Mereka akan menempatkan "real me" pada interaksi di internet dan lebih sulit dalam menunjukkan "real me" pada interaksi tatap muka (Amichai-Hamburger, Wainapel, \& Fox, 2002). Maka individu yang neuroticism akan cenderung menunjukkan diri di media sosial dengan memberikan kesan yang baik di mata teman-teman di media sosial untuk mencapai ideal self yang akan meningkatkan dukungan sosial, seperti memasang foto profil yang menarik (Michikyan, Subrahmanyam, \& Dennis, 2014). Di sisi lain, individu dengan kecenderungan conscientiousness yang tinggi akan kurang memiliki FOMO yang mengakibatkan ia memiliki penggunaan internet bermasalah yang rendah.

Selain pesatnya pengguna internet dan munculnya FOMO menarik perhatian peneliti untuk melakukan penelitian di area ini. Hal ini beresiko munculnya penggunaan internet bermasalah terutama pada usia 20-39 tahun dengan kategori usia yang paling banyak menggunakan internet. Selain itu, masih sedikit penelitian pada fenomena FOMO dan keterkaitannya dengan kepribadian dan penggunaan internet bermasalah. Maka pada penelitian ini akan melihat pengaruh FOMO pada hubungan kepribadian dan penggunaan internet bermasalah. Tujuan pada penelitian ini yaitu untuk melihat pengaruh mediator FOMO pada hubungan kepribadian dan penggunaan internet bermasalah. Hipotesis pertama yaitu adanya pengaruh mediator FOMO antara trait neuroticism dan penggunaan internet bermasalah. Hipotesis kedua yaitu adanya pengaruh mediator FOMO antara trait conscientiousness dan penggunaan internet bermasalah.

\section{Rumusan Masalah}

Permasalahan dalam penelitian ini adalah sebagai berikut:

a. Apakah terdapat pengaruh mediator fear of missing out pada hubungan antara trait neuroticism dan penggunaan internet bermasalah?

b. Apakah terdapat pengaruh mediator fear of missing out pada hubungan antara trait conscientiousness dan penggunaan internet bermasalah?

\section{METODE PENELITIAN}

\section{Desain Penelitian}

Penelitian ini merupakan penelitian non-experimental yaitu strategi penelitian yang menekankan pada studi hubungan antar variabel dengan melakukan pengukuran terhadap variabel. Tidak terdapat hal yang dimanipulasi oleh peneliti karena melakukan penelitian hal yang latent dan terjadi secara natural (Cozby \& Bates, 2015). Dalam penelitian ini, akan mengukur perilaku penggunaan internet pada individu dengan prediktor FOMO dan kepribadian dengan pengambilan data menggunakan skala yang akan diperoleh skor pada masing-masing alat ukur. Selanjutnya, dari skor tersebut akan dianalisi secara statistik. Melalui metode penelitian ini diharapkan peneliti mengetahui gambaran tentang pengaruh mediator FOMO antara kepribadian dan penggunaan internet bermasalah.

\section{Partisipan}


Partisipan penelitian adalah partisipan berjenis kelamin laki- laki $(\mathrm{N}=39)$ dan perempuan $(\mathrm{N}=$ 143) dengan rentang usia $18-29$ tahun $(\mathrm{M}=23.05, \mathrm{SD}=2.7)$ yaitu pada emerging adulthood dengan jumlah total partisipan 182 orang. Sebagian besar peneliti dalam ranah internet memilih partisipan pada emerging adulthood dengan rentang usia dari 18-29 tahun (Anderson, Steen, \& Stravopoulos, 2016; Stead \& Bibby, 2017). Jika ditinjau dari hasil survei Asosiasi Penyelenggara Jaringan Internet Indonesia (APJII) juga menunjukkan hasil bahwa pada rentang usia tersebut masuk dalam kelompok usia dengan jumlah terbanyak dalam menggunakan jaringan internet di Indonesia. Pendidikan minimal SMA dan aktif menggunakan jaringan internet setiap hari. Pendidikan partisipan bervariasi, pendidikan terkahir SMA sebanyak $35.3 \%$,pendidikan D3 $5.5 \%$, pendidikan S1 55.5\%, dan pendidikan S2 3.8\%. Pengambilan sampel penelitian ini menggunakan teknik nonprobability sampling yaitu teknik sampling yang memberikan peluang bagi populasi tidak diketahui. Adapun pada penelitian ini menggunakan salah satu bentuk teknik nonprobability sampling yaitu accidental sampling. Accidental sampling atau convenience sampling adalah pengambilan sampel dengan memilih siapa saja yang dapat dijadikan partisipan (Cozby \& Bates, 2015). Penentuan jumlah partisipan menggunakan bantuan aplikasi G-Power. Besarnya jumlah partisipan yang dibutuhkan yaitu minimal 107 partisipan . Penggunaan GPower dalam penentuan jumlah sampel penelitian ini berfungsi untuk memenuhi kekuatan pada hasil analisis statistik. Metode pengumpulan data dengan mengundang partisipan untuk mengisi skala daring internet. Partisipan diundang melalui jaringan media sosial peneliti dan rekan peneliti. Sebelum mengisi skala, peneliti memberikan penjelasan secara umum tujuan diadakannya penelitian dan kesediaan partisipan dalam penelitian ini dengan memberikan informed consent.

\section{Pengukuran}

Terdapat tiga alat ukur yang digunakan dalam penelitian ini yaitu skala penggunaan internet bermasalah, skala kepribadian, dan skala fear of missing out. Penggunaan internet bermasalah diukur menggunakan The Generalized Problematic Internet Use Scale 2 / GPIUS-2 (Caplan, 2010). Lima subskala pada penggunaan internet bermasalah yaitu: preference for online social interaction, mood regulation, cognitive preoccupation, compulsive internet use, dan negative outcomes. Terdiri dari 15 item dengan respon point 8 Likert format dari 8 (amat sangat setuju) sampai 1 (amat sangat tidak setuju). Tiap subskala terdiri dari tiga item. Contoh itemnya yaitu "Saya akan merasa kebingungan jika saya tidak dapat online." Skala ini berisi pernyataan yang terdiri dari 8 pilihan jawaban $(1=$ amat sangat tidak setuju, $8=$ amat sangat setuju). Skoring dilakukan dengan menjumlahkan skor dari item nomor 1 sampai 15, maka akan diperoleh skor total. Skor tertinggi pada skala ini 120 dan skor terendah 15. Alat ukur ini telah dilakukan dilakukan pengujian validitas dan reliabilitas. Pengujian validitas dapat dilihat pada nilai itemtotal correlation yaitu berkisar antara 0,284-0,697 pada skala ini. Selanjutnya untuk pengujian reliabilitas, koefisien alpha cronbach alat ukur ini sebesar 0,857.

Skala untuk mengukur kepribadian menggunakan The Big Five Personality Inventory (Ramdhani, 2012) terdiri dari 15 item dengan skala Likert dengan 7 poin skala dari 1 (Sangat tidak setuju) sampai dengan 7 (Sangat setuju). Selanjutnya, Alat ukur BFI terdiri dari favorable dan unfavorable item dengan 7 item mengukur conscientiousness dan 8 item mengukur neuroticism. Contoh itemnya yaitu "gigih mengerjakan tugas hingga selesai." Skala ini berisi pernyataan yang terdiri dari 7 pilihan jawaban $(1=$ amat sangat tidak setuju, $7=$ amat sangat setuju). Selanjutnya, pemberian skor sesuai dengan pilihan jawaban yang ada. Skoring dilakukan dengan menjumlahkan skor pada tiap-tiap trait dan pemberian skor dibalik untuk item nonfavorable. Melalui skor total tersebut yang selanjutnya akan di analisis. Alat ukur ini telah di uji validitas dengan melihat nilai item-total correlation yaitu berkisar antara 0,293-0,730. 
Sedangkan untuk uji reliabilitas, koefisien alpha Cronbach pada trait conscientiousness sebesar 0,832 dan, trait neuroticism sebesar 0,824 .

Fear of missing out diukur menggunakan skala Fear of missing out Scale (FOMOs) yang di susun oleh Przybylski, dkk (2013). FOMOs bersifat unidimensional dan terdiri dari 10 item dengan respon point 5 Likert format dari sangat sesuai sampai sangat tidak sesuai. Contoh item sebagai berikut "Jika saya melewatkan rencana pergi bersama teman saya akan merasa tidak senang." Skala ini berisi pernyataan yang terdiri dari 5 pilihan jawaban $(1=$ sangat tidak sesuai, 5 = amat sangat sesuai). Skoring dilakukan dengan menjumlahkan skor dari item nomor 1 sampai 10, maka akan diperoleh skor total. Skor tertinggi pada skala ini 50 dan skor terendah 10. Melalui skor total tersebut yang selanjutnya akan di analisis. Alat ukur ini telah dilakukan pengujian validitas dengan melihat nilai item-total correlation yaitu berkisar antara 0,266-0,794. Selanjutnya untuk pengujian reliabilitas, koefisien alpha Cronbach alat ukur ini sebesar 0,787.

\section{Analisis Data}

Analisis data yang digunakan dalam penelitian ini yaitu analisis mediasi. Analisis mediasi adalah metode statistik yang digunakan untuk menjawab pertanyaan bagaimana prediktor $\mathrm{X}$ diduga mempengaruhi hasil Y melalui intervensi dari variabel M (Hayes, 2013). Untuk melakukan analisis ini diperlukan aplikasi IBM SPSS versi 21 dengan process macro dari Hayes.

\section{HASIL DAN PEMBAHASAN \\ Hasil}

Skor minimum, maksimum, rata-rata, dan standar deviasi pada tiap skala akan dijelaskan dalam tabel 1. Conscientiousness dan neuroticism memiliki skor rata-rata yang hampir sama (rata-rata hipotetik alat ukur neuroticism $=32$, rata-rata hipotetik alat ukur conscientiousness $=28$ ). Pada FOMO dan penggunaan internet bermasalah memiliki skor rata-rata yang hampir sama dengan skor rata-rata hipotetik alat ukur (rata-rata $\mathrm{FOMO}=30$, rata-rata penggunaan internet bermasalah=67,5). Lebih jelas dapat dilihat pada tabel 1.

Tabel 1. Hasil deskriptif partisipan

\begin{tabular}{ccccc}
\hline Variabel & Minimum & Maximum & Rata-rata & Standar deviasi \\
\hline Conscientiousness & 17 & 49 & 33,4 & 6,2 \\
Neuroticism & 14 & 53 & 33,6 & 7,6 \\
FOMO & 10 & 46 & 28,3 & 6,9 \\
Penggunaan Internet & 15 & 120 & 59,7 & 19,1 \\
Bermasalah & & & & \\
\hline
\end{tabular}

Hasil utama penelitian akan menjabarkan hasil mediasi pada variabel kepribadian (neuroticism dan conscientiousness), FOMO, dan penggunaan internet bermasalah. Hasil mediasi FOMO pada hubungan neuroticism terhadap penggunaan internet bermasalah dapat dilihat pada tabel 2 dan gambar 1. Pada tabel 2 menunjukkan bahwa trait neuroticism mempengaruhi FOMO secara signifikan, $\mathrm{a}=0,268, \mathrm{p}<0,001$. Kemudian, FOMO mempengaruhi penggunaan internet bermasalah secara signifikan, $\mathrm{b}=0,941, \mathrm{p}<0,001$. Selanjutnya, trait neuroticism mempengaruhi penggunaan internet bermasalah melalui mediator yaitu FOMO secara signifikan, c' $=0,615$, $\mathrm{p}<0,001$. Maka diperoleh indirect effect sebesar 0,247, direct effect sebesar 0,615, dan total effect sebesar 0,863. Indirect effect sebesar 0,247 pada 10.000 bootstrap sampel dan diperoleh true indirect effect yang berkisar antara 0,102 hingga 0,415 pada 95\% Confidence Interval (CI). 
Tabel 2. Model Koefisien Penggunaan Internet Bermasalah

\begin{tabular}{|c|c|c|c|c|c|c|c|c|}
\hline \multirow{3}{*}{ Prediktor } & & & & & & \multicolumn{3}{|c|}{ Akibat } \\
\hline & \multicolumn{4}{|c|}{$\begin{array}{c}M \\
\text { (FOMO) }\end{array}$} & & \multicolumn{3}{|c|}{$\begin{array}{c}\mathrm{Y} \\
\text { (Penggunaan Internet Bermasalah) }\end{array}$} \\
\hline & & Coeff. & $S E$ & $P$ & & Coeff. & $S E$ & $P$ \\
\hline $\mathrm{X}$ (Neuroticism) & $\bar{A}$ & 0,268 & 0,066 & $<0,001$ & $c^{\prime}$ & 0,615 & 0,178 & $<0,001$ \\
\hline M (FOMO) & & - & - & - & $B$ & 0,941 & 0,191 & $<0,001$ \\
\hline \multirow[t]{2}{*}{ Constant } & $i_{1}$ & 19,458 & 2,283 & $<0,001$ & $i_{2}$ & 12,632 & 6,939 & 0,070 \\
\hline & \multicolumn{5}{|c|}{$\begin{array}{c}\mathrm{R}^{2}=0,080 \\
F(1,180)=15,683, p<0,001\end{array}$} & \multicolumn{3}{|c|}{$\begin{array}{c}\mathrm{R}^{2}=0,218 \\
F(2,179)=24,939, p<0,001\end{array}$} \\
\hline
\end{tabular}

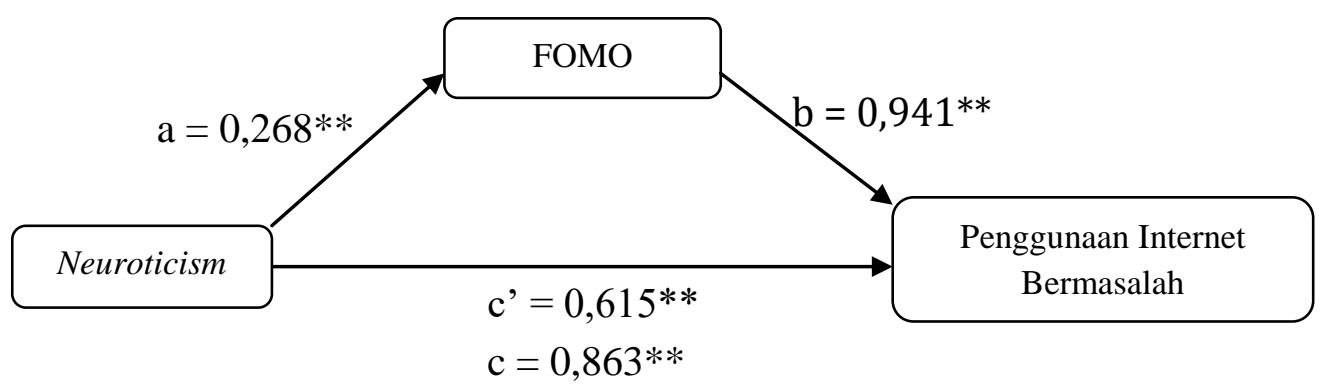

Gambar 1. Hasil mediasi

Hasil mediasi FOMO pada hubungan conscientiousness terhadap penggunaan internet bermasalah ditunjunkkan pada tabel 3 dan gambar 2. Pada proses mediasi menunjukkan bahwa trait conscientiousness mempengaruhi FOMO secara signifikan, $\mathrm{a}=-0,241, \mathrm{p}<0,05$. Kemudian, FOMO mempengaruhi penggunaan internet bermasalah secara signifikan, $b=1,050, p<0,001$. Selanjutnya, trait conscientiousness mempengaruhi penggunaan internet bermasalah melalui mediator yaitu FOMO secara signifikan, $\mathrm{c}^{\prime}=-0,407, \mathrm{p}=0,059$. Maka diperoleh indirect effect sebesar -0,253, direct effect sebesar -0,407, dan total effect sebesar -0,660. Indirect effect sebesar -0,253 pada 10.000 bootstrap sampel dan diperoleh true indirect effect yang berkisar antara 0,476 hingga -0,072 pada 95\% Confidence Interval (CI).

Tabel 3. Model Koefisien Penggunaan Internet Bermasalah

\begin{tabular}{|c|c|c|c|c|c|c|c|c|}
\hline \multirow{3}{*}{ Prediktor } & & & & & & \multicolumn{3}{|c|}{ Akibat } \\
\hline & \multicolumn{4}{|c|}{$\begin{array}{c}M \\
(\mathrm{FOMO})\end{array}$} & & \multicolumn{3}{|c|}{$\begin{array}{c}\mathrm{Y} \\
\text { (Penggunaan Internet Bermasalah) }\end{array}$} \\
\hline & & Coeff. & $S E$ & $P$ & & Coeff. & $S E$ & $P$ \\
\hline X (Conscientiousness) & $a$ & $-0,241$ & 0,081 & $<0,05$ & $c^{\prime}$ & $-0,407$ & 0,214 & 0,059 \\
\hline M (FOMO) & & - & - & - & $B$ & 1,050 & 0,192 & $<0,001$ \\
\hline \multirow[t]{2}{*}{ Constant } & $i_{1}$ & 36,287 & 2,749 & $<0,001$ & $i_{2}$ & 43,737 & 9,940 & $<0,001$ \\
\hline & \multicolumn{5}{|c|}{$\begin{array}{c}\mathrm{R}^{2}=0,046 \\
F(1,180)=8,760 p<0,05\end{array}$} & \multicolumn{3}{|c|}{$\begin{array}{c}\mathrm{R}^{2}=0,182 \\
F(2,179)=19,906, p<0,001\end{array}$} \\
\hline
\end{tabular}

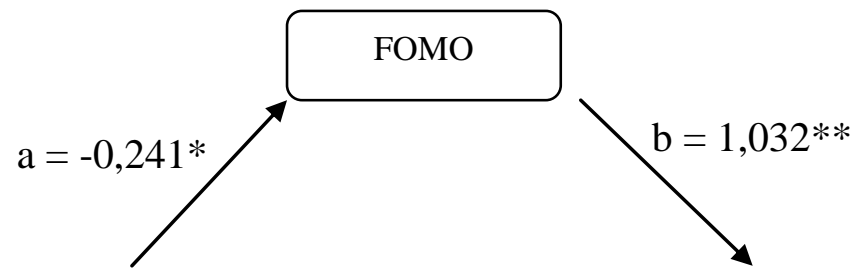




\begin{tabular}{c} 
Conscientiousness \\
\cline { 2 - 3 } \\
$\mathrm{c}^{\prime}=-0,407$ \\
$\mathrm{c}=-0,660 *$
\end{tabular}$\longrightarrow$\begin{tabular}{c}
$\begin{array}{c}\text { Penggunaan Internet } \\
\text { Bermasalah }\end{array}$ \\
\hline
\end{tabular}

Gambar 2. Hasil mediasi

\section{Pembahasan}

Jaringan internet dapat menjadi hal yang positif jika mendukung aspek-aspek kehidupan individu. Namun, dapat pula menjadi hal yang negatif jika mengganggu keberfungsian individu dalam kehidupan sehari-harinya seperti mengganggu secara psikologis, sosial, sekolah, dan pekerjaan (Spada, 2014). Melalui penelitian ini menemukan penggunaan internet bermasalah dapat diprediksi oleh trait neuroticism dan conscientiousness melalui FOMO. FOMO dapat mendorong individu untuk selalu memantau kegiatan teman melalui jaringan internet. Sehingga, penggunaan internet menjadi berlebihan dan dapat mengganggu ke dalam aktivitas harian.

FOMO tidak memediasi penuh pada trait neuroticism terhadap penggunaan internet bermasalah karena kedua variabel tersebut memiliki satu karakteristik yang hampir sama yaitu adanya perasaan takut. Pada trait neuroticism, individu memiliki ketakutan yang lebih umum dibandingkan pada FOMO. Pada FOMO, ketakutan yang dimiliki individu lebih spesifik yaitu ketakutan akan diabaikan oleh teman dan orang-orang disekitarnya. Sehingga, keduanya samasama dapat mempengaruhi penggunaan internet bermasalah secara langsung. Selain itu, neuroticism juga mempengaruhi penggunaan internet bermasalah secara signifikan.

Trait neuroticism memiliki karakteristik adanya emosi negatif yang ada pada individu yang tinggi pada trait ini. Rasa cemas dan takut menjadi ciri khas pada individu yang neuroticism. Mood juga mudah berubah-ubah dikarenakan emosi yang kurang stabil. Beberapa akan cenderung mudah untuk mengalami depresi (Costa \& McCrae, 2003). Karakteristik-karateristik tersebut akan terlihat saat menjalin hubungan sosial. Maka akan memicu hubungan yang tidak stabil dengan orang lain (Lahey, 2009). Neuroticism juga memprediksi kelekatan kecemasan (attachment anxiety) secara umum. Individu yang neurotik membangun pemikiran jika orang sekitar mereka cenderung untuk menolak kehadiran dan mengabaikan mereka (Holmberg, McWilliams, \& Patterson, 2012). Sehingga mereka akan kesulitan dalam mengatur hubungan dengan orang lain, sedangkan ia harus tetap bersosialisasi. Salah satunya dengan memantau perkembangan teman-temannya melalui jaringan internet (Przybylski, dkk, 2013). Mood yang berubah-ubah dan kecemasan dalam pertemanan juga dapat menimbulkan ketakutan jika tidak dilibatkan dalam momen yang menyenangkan bersama teman (Oberst, dkk, 2016 \& Przybylski, dkk, 2013). Akhirnya membuat mereka selalu mengecek kabar teman melalui jaringan internet dan dapat meningkatkan penggunaan internet mereka.

Conscientiousness yang rendah memiliki karakteristik hidup kurang terstruktur, kurang bersemangat, dan terkadang tidak tepat waktu dapat menurunkan kualitas hubungan dengan orang lain (Costa \& McCrae, 2003). Crawford (2007) menjelaskan bahwa conscientiousness yang rendah merepresentasikan individu yang kurang dapat meregulasi emosi. Pada penelitian Holmberg, McWilliams, \& Patterson (2012) menemukan kelekatan kecemasan (attachment anxiety) terhadap teman dekat dipengaruhi oleh rendahnya conscientiousness individu. Secara umum, kelekatan kecemasan dikarakteristikkan sebagai individu yang mengalami emosi negatif 
(ketakutan akan penolakan dan pengabaian). Jika conscientiousness inidividu rendah, mereka kurang dapat mengatur emosi negatif sehingga mereka sulit dalam mengontrol kecemasan dan ketakutan mereka (Holmberg, McWilliams, \& Patterson, 2012). Hal ini memunculkan FOMO dengan takut tidak terlibat dalam kegiatan menyenangkan bersama teman. Akhirnya, mereka selalu memantau kabar teman melalui internet. Selain itu, conscientiousness berkorelasi negatif dengan penerimaan terhadap teman sebaya, hubungan resiprokal, dan kualitas pertemanan (Jensen-Campbell \& Malcolm, 2007). Hal ini memunjukkan bahwa conscientiousness yang rendah akan lebih bermasalah dalam pertemanan karena mereka kurang diterima oleh temantemannya dan membangun kualitas pertemanan yang buruk. Untuk tetap dapat menjalin hubungan dengan teman mereka selalu memantau kabar teman, salah satunya melalui jaringan internet.

Beberapa penelitian sebelumnya pada variabel penggunaan internet bermasalah tidak memberikan karakteristik secara khusus dalam pemilihan partisipan (Bibby \& Stead, 2017; Durak \& Senol-Durak, 2014; Caplan, 2010). Sebagian besar memberikan karakteristik partisipan aktif menggunakan internet setiap harinya dan tidak ada minimal waktu yang digunakan. Penggunaan internet bermasalah tidak dipertimbangkan sebagai gangguan mental (Laconi, Vigouroux, Lafuenta, \& Chabrol, 2017) namun diperlukan karakteristik khusus dalam menentukan partisipan seperti memilih partisipan pada dalam kategori tinggi pada penggunaan internet bermasalah. Agar mendapatkan gambaran mengenai partisipan lebih jelas yaitu partisipan yang memiliki masalah dalam menggunakan internet.

Berdasarkan hasil yang didapatkan dalam penelitian ini menyatakan bahwa FOMO berhasil menjadi mediator antara hubungan kepribadian (trait neuroticism dan conscientiousness) dan penggunaan internet bermasalah. FOMO memiliki pengaruh yang cukup kuat pada penggunaan internet bermasalah sehingga dapat menjadi mediator yang juga kuat antara keperibadian dengan penggunaan internet bermasalah. Individu yang cenderung menggunakan internet secara bermasalah dapat dipengaruhi oleh kepribadian melalui FOMO. Trait neuroticism dan conscientiousness, keduanya sama-sama memiliki pengaruh terhadap FOMO. Munculnya FOMO kuat kaitannya dengan penggunaan internet secara berlebihan. Karena semakin individu FOMO maka semakin tinggi penggunaan internet bermasalah. Hal ini mengartikan bahwa FOMO menjadi mediasi pada hubungan antara neuroticism dan conscientiousness terhadap penggunaan internet bermasalah.

\section{KESIMPULAN DAN SARAN}

\section{Kesimpulan}

Berdasarkan hasil yang didapatkan dalam penelitian ini bahwa FOMO berhasil menjadi mediator antara hubungan kepribadian (trait neuroticism dan conscientiousness) dan penggunaan internet bermasalah. Penggunaan internet bermasalah dapat dipengaruhi oleh kepribadian melalui FOMO. Trait neuroticism dan conscientiousness, keduanya sama-sama memiliki pengaruh terhadap FOMO. Munculnya FOMO kuat kaitannya dengan penggunaan internet secara berlebihan. Semakin individu FOMO maka semakin tinggi penggunaan internet bermasalah. Hal ini mengartikan bahwa FOMO dapat menjadi mediasi antara neuroticism dan conscientiousness terhadap penggunaan internet bermasalah.

\section{Saran}


Saran untuk penelitian ini yaitu untuk dapat lebih memberikan karakteristik-karakteristik yang lebih spesifik dalam pemilihan partisipan pengguna internet yang bermasalah. Agar lebih dapat menggambarkan penelitian yang bertujuan untuk mendapatkan gambaran individu yang memiliki masalah dalam penggunaan internet. Kemudian, untuk penelitian selanjutnya, dapat mengaitkan FOMO dengan variabel lain seperti regulasi emosi. Pada penelitian sebelumnya, ditemukan individu yang memiliki regulasi emosi yang buruk akan cenderung mudah cemas dan takut menjalin hubungan dengan orang lain. Maka dimungkinkan FOMO berkorelasi dengan regulasi emosi yang buruk.

\section{Ucapan Terima Kasih (Acknowledgement)}

Peneliti mengucapkan terima kasih kepada partisipan yang telah meluangkan waktunya untuk mengikuti penelitian ini. Peneliti juga mengucapkan terima kasih kepada pihak universitas yang telah mendukung penelitian ini.

\section{REFERENSI}

Anderson, E. L., Steen, E., \& Stavropoulos, V. (2016). Internet use and Problematic Internet Use: a systematic review of longitudinal research trends in adolescence and emergent adulthood, International Journal of Adolescence and Youth, 22, 430-454.

Amichai-Hamburger, Y., Wainapel, G., \& Fox, S. (2002). ' On the Internet no one knows I'm an introvert': Extroversion, neuroticism, and Internet interaction. CyberPsychology and Behavior, 5, 125-128.

Asosiasi Penyelenggara Jasa Internet Indonesia. (2016, november). Saatnya jadi pokok perhatian pemerintah dan industri, Buletin APJII, 1.

Blackwell, D., Leaman, C., Tramposh, R., Osborne, C., \& Liss, M. (2017). Extraversion, neuroticism, attachment style and fear of missing out as predictors of social media use and addiction, Personality and Individual Differences, 166, 69-72.

Caplan, S. E. (2002). Problematic Internet use and psychosocial well-being: Development of a theory-based cognitive-behavioral measure. Computers in Human Behavior, 18, 533-575.

Caplan, S. E. (2010). Theory and measurement of generalized problematic Internet use: A twostep approach, Computers in Human Behavior, 26, 1089-1097.

Ceyhan, E. (2007, November). University students' problematic internet use in terms of reasons for internet use. Paper presented at 6th WSEAS International Conference on Education and Educational Technology, Italy.

Cozby, P.C., \& Bates, S. (2015). Methods in Behavioral Research $12^{\text {th }}$ Edition. New York: McGraw Hill.

Crawford, T. N., Shaver, P. R., \& Goldsmith, H. H. (2007). How affect regulation moderates the association between anxious attachment and neuroticism. Attachment \& Human Development, 9, 95-109.

Davis, R. A. (2001). A cognitive-behavioral model of pathological Internet use. Computers in Human Behavior, 17, 187-195.

Durak, M., \& Senol-Durak, E. (2014). Which personality traits are associated with cognitions related to problematic internet use? Asian Journal of Social Psychology, 17, 206-218.

Floros, G, \& Siomos, K. (2014). Excessive internet use and personality traits. Current Behavioral Neuroscience Reports, 1, 19-26. 
Gámez-Guadix, M. (2014). Depressive symptoms and problematic Internet use among adolescents: Analysis of the Longitudinal relationships from the cognitive-behavioral model. CyberPsychology, Behavior, and Social Networking, 17, 714-719.

Hayes, A. F. (2013). Introduction to mediation, moderation, and conditional process analysis A regression based approach. New York: The Guildford Press.

Jackson, L. A., von Eye, A., Biocca, F., Barbatsis, G., Fitzgerald, H., \& Zhao, Y. (2003). Personality, cognitive style, demographic characteristics and Internet use: Findings from the HomeNetToo. Swiss Journal of Psychology, 62, 79-90.

Jensen-Campbell, L. A., \& Malcolm, K. T. (2007). The importance of conscientiousness in adolescent interpersonal relationships, Society for Personality and Social Psychology, 33, 368-383.

Kopunicova, V., \& Baumgartner, F. (2016). Personality, depression, and problematic internet use, Psychoogy and its Contexts, 7, 81-92.

Laconi, S., Vigouroux, M., Lafuente, C., \& Chabrol, H. (2017). Problematic internet use, psychopathology, personality, defense and coping, Computers in Human Behavior, 73, 4756.

Lahey, B. B. (2009). Public health significance of neuroticism. American Psychologist, 64(64), 241-256.

Lenhart, A. (2015, April). Teens, social media \& technology overview 2015. Ditemu kembali http:// www.pewinternet.org/2015/04/09/teenssocial-media-technology-2015/.

McCrae, R. R., \& Costa, Jr., P. T. (2003). Personality in adulthood a five-factor theory perspective $2^{\text {nd }}$ edition. The Guilford Press: New York.

\section{Michikyan, M., Subrahmanyam, K., \& Dennis, J. (2014). Can you tell who I am? Neuroticism, extraversion, and online self-presentation among young adults. Computers in Human Behavior, 33, 179-183.}

Oberst, U.,Wegmann, E., Stodt, B., Brand, M., \& Chamarro, A. (2016). Negative consequences from heavy social networking in adolescents: The mediating role of fear of missing out, Journal of Adolescence, 55, 51-60.

Przybylski, A. K., Murayama, K., DeHaan, C. R., \& Gladwell, V. (2013). Motivational, emotional, and behavioral correlates of fear of missing out, Computers in Human Behavior, 29, 1841-1848.

Ramdhani, N. (2012). Adaptasi bahasa dan budaya inventori Big Five, Jurnal Psikologi, 39, 189207.

Spada, M. M. (2014). An overview of problematic internet use. Addictive Behaviors, 39, 3-6.

Stead, H., \& Bibby, P. A. (2017). Personality, fear of missing out and problematic internet use and their relationship to subjective well-being, Computers in Human Behavior, 76, 534540 .

Thorsteinsson, E. B., \& Davey, L. (2014). Adolescents' compulsive Internet use and depression: A longitudinal study. Open Journal of Depression, 3, 13-17. 